\title{
Performance of high yielding varieties of mustard in cluster front line demonstration using sulphur and zinc under Hathras condition
}

\author{
Shyam Singh \\ Krishi Vigyan Kendra, Banda University of Agriculture and Technology, Banda (U.P.) India \\ (Email: shyamsingh15350@gmail.com)
}

\begin{abstract}
Present study was carried-out during Rabi seasons of 2016-17 and 2017-18 at farmer's fields of four blocks in Hathras district of Uttar Pradesh. Clusters front line demonstration (CFLD) on mustard crop was conducted on an area of 30 ha with active participation of 75 farmers with improved technologies composed of RH-749 and Giriraj varieties and integrated crop management (Sulphur @ $40 \mathrm{~kg} / \mathrm{ha}+$ Zinc Sulphate @ $25 \mathrm{~kg} / \mathrm{ha}+$ Line sowing following Thinning + seed treated with thiram 75\% WP @ 3g/kg seed). The results revealed that maximum mean grain yield $24.89 \mathrm{q} / \mathrm{ha}$ with an increase in 24.18 per cent over farmers practice (20.04 $\mathrm{q} / \mathrm{ha}$ ). Improved demonstrated technologies of mustard cultivation recorded increased average grain yield during both the years of study. The RH-749 variety gave higher yield as compared to both Giriraj and local check variety Rohini during both the years. The extension gap can be bridged by popularizing package of practices of mustard including improved variety (RH-749), use of optimum seed rate in line sowing, Sulphur @ 40 kg/ha, Zinc Sulphate@ 25 kg/ha, balanced nutrition and recommended plant protection measures. Improved technologies gave higher net return of Rs. 50,555/ha with benefit cost ratio of 2.53 as compared to net return from farmers practice Rs. 39,778/ha with benefit cost ratio of 2.40.
\end{abstract}

Key Words : Mustard Variety RH-749, Giriraj, Yield, HI, FLD, Benefit cost ratio

View Point Article : Singh, Shyam (2020). Performance of high yielding varieties of mustard in cluster front line demonstration using sulphur and zinc under Hathras condition. Internat. J. agric. Sci., 16 (2) : 160-165, DOI:10.15740/HAS/IJAS/16.2/160-165. Copyright@ 2020: Hind Agri-Horticultural Society.

Article History : Received : 15.03.2020; Revised : 28.04.2020; Accepted : 04.05.2020 